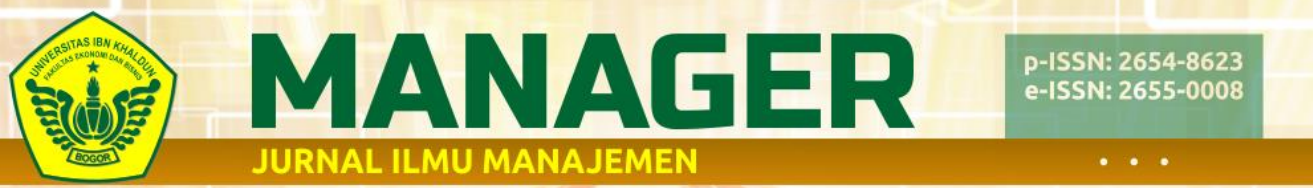

Vol. 2, No. 2, Mei 2019, Hal 183-195@ @() http://ejournal.uikabogor.ac.id/index.php/Manager/index

\title{
EFFECT OF WORK ETHOS AND WORK SATISFACTION ON EMPLOYEE PERFORMANCE
}

\author{
Noviana Andiningrum, Azis Firdaus dan Rachmatullaily Tinakartika Rinda \\ Nandiningrum@gmail.com, azisfirdaus@uika-bogor.ac.id,lailyrinda@yahoo.com \\ Fakultas Ekonomi dan Bisnis Universitas Ibn Khaldun Bogor
}

\begin{abstract}
Abstrak
Penelitian ini bertujuan untuk mengetahui dan menganalisis pengaruh etos kerja dan kepuasan kerja terhadap kinerja karyawan PT Mercedes Benz Indonesia. Teknik pengambilan sampel menggunakan random sampling dengan menyebarkan kuesioner kepada karyawan PT Mercedes Benz Indonesia secara acak. Metode analisis yang digunakan adalah metode analisis deskriptif, metode analisis statistik yang terdiri dari regresi, analisis linier, pengujian signifikansi parsial (uji t) dan pengujian koefisien determinasi. Dan itu sampel dalam penelitian ini adalah 50 responden. Ini ditunjukkan dari hasil persamaan regresi $\mathrm{Y}$ $=29,008$ 0,178 X1 0,142 X2 dengan interpretasi variabel X1 (etos kerja) sebesar 0,178 dan interpretasi variabel X2 (kepuasan kerja) sebesar 0,142. Berdasarkan statistik uji korelasi yang penulis lakukan, diperoleh koefisien korelasi sebesar 0,252 yang berarti hubungan rendah. Jadi dapat disimpulkan bahwa jika X1 dan $\mathrm{X} 2$ naik maka $\mathrm{Y}$ juga akan naik. Karena fcount $=1,597 \mathrm{ftabel}=.20$, then $\mathrm{Ho}$ is rejected by $\mathrm{Ha}$ accepted, meaning there is no significant influence between work ethic and job satisfaction on employee performance. Keyword : Work Ethics, Job Satisfaction, Performance $=3,20$, maka Ho ditolak oleh Ha diterima, artinya tidak ada pengaruh yang signifikan antara etos kerja dan kepuasan kerja terhadap kinerja karyawan.
\end{abstract}

Kata Kunci: Etika Kerja, Kepuasan Kerja, Kinerja

\begin{abstract}
This study aims to determine and analyze the effect of work ethic and job satisfaction on the performance of employees of PT Mercedes Benz Indonesia. The sampling technique used random sampling by distributing questionnaires to employees of PT Mercedes Benz. Indonesia randomly. The analytical method used is descriptive analysis method, statistical analysis method consisting of regression, linear analysis, partial significance testing (t-test) and testing the coefficient of determination. And the sample in this study was 50 respondents. This is shown from the results of the regression equation $Y=29.008+0.178 X 1$ $+0.142 X 2$ with the interpretation of variable X1 (work ethic) of 0.178 and the
\end{abstract}


interpretation of X2 variables (job satisfaction) of 0.142. Based on the correlation test statistics that the author did, obtained the correlation coefficient of 0.252 which means low relationship. So it can be concluded that if X1 and X2 rise then $Y$ will also rise. Because fcount $=1.597<$ ftabel $=3.20$, then $\mathrm{Ho}$ is rejected by Ha accepted, meaning there is no significant influence between work ethic and job satisfaction on employee performance.

Keyword : Work Ethics, Job Satisfaction, Performance

\section{Pendahuluan Latar Belakang}

Pertumbuhan ekonomi yang tinggi dan berkelanjutan merupakan kondisi utama atau suatu keharusan bagi kelangsungan pembangunan ekonomi dan peningkatan kesejahteraan. Jumlah penduduk bertambah setiap tahunnya, dan dengan sendirinya jumlah permintaan dan penawaran juga bertambah setiap tahunnya, sehingga akan menciptakan suatu kondisi dengan perluasan kesempatan kerja yang dapat mengurangi adanya ketimpangan. Namun, perluasan kesempatan kerja juga harus diimbangi dengan sumber daya manusia yang berkualitas. Kinerja karyawan yang tinggi sangatlah diharapkan oleh perusahaan tersebut. Semakin banyak karyawan yang mempunyai kinerja tinggi, maka produktivitas perusahaan secara keseluruhan akan meningkat sehingga perusahaan akan dapat bertahan dalam persaingan global. Terdapat faktor negatif yang dapat menurunkan kinerja karyawan, diantaranya adalah menurunnya keinginan karyawan untuk mencapai prestasi kerja, kurangnya ketepatan waktu dalam penyelesaian pekerjaan sehingga kurang menaati peraturan, pengaruh yang berasal dari lingkungannya, teman sekerja yang juga menurun semangatnya dan tidak adanya contoh yang harus dijadikan acuan dalam pencapaian prestasi kerja yang baik. Semua itu merupakan sebab menurunya kinerja karyawan dalam bekerja. Faktorfaktor yang dapat digunakan untuk meningkatkan kinerja diantaranya adalah etos kerja dan kepuasan kerja karyawan.

Dalam berorganisasi, etos kerja sangat menentukan kinerja seseorang melaksanakan tugas dan kewajibanya. Jika ia dalam kondisi beretos tinggi, sangat besar kemungkinan banyak pekerjaan yang bisa terselesaikan dengan mudah, namun sebaliknya jika kondisi jiwanya dalam keadaaan etos kerja yang kurang maksimal, maka besar kemungkinan juga kinerjanya dalam melaksanakan tugas juga menurun.

Dari kata etos ini dikenal pula kata etika, etiket yang hampir mendekati pada pengertian akhlak atau nilainilai yang berkaitan dengan baik buruk (moral), sehingga dalam etos tersebut terkandung gairah atau semangatyang amat kuat untuk mengerjakan sesuatu secara optimal, lebih baik dan bahkan berupaya untuk mencapai kualitas kerja yang sesempurna mungkin. Sebagai suatu subjek dari arti etos tersebut adalah etika yang berkaitan dengan konsep yang dimiliki oleh individu maupun 
kelompok untuk menilai apakah tindakan-tindakan yang telah dikerjakan itu salah atau benar,buruk atau baik.

PT.Mercedes-Benz Indonesia merupakan salah satu perusahaan mobil yang besar dan cukup ber gengsi di Bogor. Sebagai perusahaan mobil yang besar, tentunya diharapkan mampu menunjukkan kinerja terbaiknya kepada para

\section{Tujuan Penelitian}

Tujuan penulis dalam penelitian ini adalah sebagai berikut :

1. Untuk mengetahui pengaruh etos kerja terhadap kinerja karyawan PT Mercedes Benz Indonesia.

2. Untuk mengetahui pengaruh kepuasan kerja karyawan

II. Metodelogi Penelitian

Metodologi Penelitian

\section{Desain Penelitian}

Menurut M.Azis Firdaus dalam bukunya yang berjudul "Metode Penelitian", mengatakan bahwa desain riset mencerminkan apa dan bagaimana suatu riset dilakukan. Secara keseluruhan kegiatan riset dimulai dari perencanaan, pelaksanaan dan pembuatan kesimpulan tersirat dari desain yang disusun peneliti. Desain Eksplorasi

\section{Variabel Dan Pengukuran}

Pada penelitian ini, variabel yang digunakan adalah variabel bebas berupa etos $\operatorname{kerja}\left(\mathrm{X}_{1}\right)$ dan kepuasan kerja $\left(\mathrm{X}_{2}\right)$, sedangkan konsumen/ penggunanya agar para konsumen/pengguna merasa nyaman saat mendapatkan pelayanan dari perusahaan ini, khususnya oleh setiap karyawan.

Hal inilah yang melatarbelakangi dan mendorong penulis mengangkat permasalahan ini melalui judul, “ Pengaruh Etos Kerja dan Kepuasan Kerja Terhadap Kinerja Karyawan pada PT.Mercedes-Benz Indonesia"

terhadap kinerja karyawan PT Mercedes Benz Indonesia.

3. Untuk mengetahui bagaimana pengaruh etos kerja dan kepuasan kerja karyawan terhadap kinerja karyawan PT Mercedes Benz Indonesia

variabel terikatnya adalah kinerja (Y).

1. Variabel Independen/ variabel bebas (X) merupakan variabel yang mempengaruhi atau yang menjadi sebab perubahannya atau timbulnya variabel dependen. (Sugiyono, 2015:39)

2. Variabel dependen/ variabel terikat merupakan variabel yang dipengaruhi atau yang menjadi akibat karena adanya variabel bebas. (Sugiyono, 2015:39)

\section{Metode Analisis Data Uji Validitas}

Validitas adalah suatu ukuran yang menunjukkan tingkat-tingkat kevalidan atau kesahihan suatu instrumen. Suatu instrumen dikatakan valid apabila mampu mengukur apa yang diinginkan dan dapat mengungkap data dari variabel yang diteliti secara tepat. Uji validitas dilakukan untuk mengetahui 
apakah alat ukur yang telah disusun benar-benar mampu mengukur apa yang harus diukur. Cara yang dipakai dalam menguji tingkat validitas adalah dengan variabel internal, yaitu menguji apakah terdapat kesesuaian antara bagian instrumen secara keseluruhan. Untuk mengukurnya menggunakan analisis butir. Kevalidan masing-masing pertanyaan dapat dilihat dari nilai corrected item total correlation dari masing-masing pertanyaan. Suatu butir pertanyaan dikatakan valid apabila nilai r-hitung yang merupakan nilai dari corrected item total correlation > r-tabel. Pengukuran pada analisis butir yaitu dengan cara skor-skor yang ada kemudian dikorelasikan dengan menggunakan rumus korelasi product moment sebagai berikut :

$$
=\frac{n \sum X Y-\sum X \cdot \sum Y}{\sqrt{n \sum X^{2}-\left(\sum X\right)^{2} \cdot n \sum Y^{2}-\left(\sum X\right)^{2}}}
$$

(Suharsimi Arikunto, 2002:146)

\section{Uji Reliabilitas}

Menurut Arikunto (2002:154), Reliabilitas adalah suatu instrumen cukup dapat dipercaya untuk digunakan sebagai alat pengumpul data karena instrumen ini sudah baik. Pada penelitian ini untuk mencari uji reliabilitas instrumen menggunakan rumus alpha $a$, karena instrumen dalam penelitian ini berbentuk angket atau daftar pertanyaan yang skornya merupakan rentangan antara 1-5 dan uji validitas menggunakan item total, dimana untuk mencari reliabilitas instrumen yang skornya bukan 1 dan 0 , misalnya angket atau soal berbentuk uraian maka menggunakan rumus alpha $a$.

Reliabilitas

merupakan sejauh mana hasil suatu pengukuran dapat dipercaya, maksudnya apabila dalam beberapa pelaksanaan pengukuran terhadap kelompok yang sama diperoleh hasil yang relatif sama. Dalam penelitian ini, uji validitas dilakukan dengan menggunakan tekhnik Formula Alpha Cronbanch dan dengan menggunakan program komputer.

Rumus Formula Alpha Cronbanch, yaitu :

$r_{i}=\left(\frac{k}{k-1}\right)\left(1-\frac{\sum \sigma_{b^{2}}}{\sigma_{t^{2}}}\right)$

(Heri Retnawati,2015:45)

\section{Analisis Regresi Sederhana}

Menurut (Prof.Dr.Sugiyono, 2016, p. 261), analisis regresi sederhana didasarkan pada hubungan fungsional ataupun kasual suatu variabel independen dengan variabel dependen. Analisis regresi sederhana berguna untuk mendapatkan hubungan fungsional antara dua variabel atau lebih atau mendapatkan pengaruh antara variabel prediktor terhadap variabel kriteriumnya atau meramalkan pengaruh pengaruh variabel prediktor terhadap variabel kriterianya.

Rumus Regresi Sederhana :

$Y=a+b X$

\section{Analisis Regresi Linear Berganda}

Analisis regresi linier berganda adalah hubungan secara linier antara dua atau lebih variabel independen $\left(\mathrm{X}_{1}, \mathrm{X}_{2}, \ldots \ldots \ldots . \mathrm{X}_{\mathrm{n}}\right)$ dengan variabel dependen (Y). Analisis ini untuk mengetahui antara hubungan antara variabel independen berhubungan positif atau negatif dan untuk memprediksi nilai dari variabel dependen apabila nilai variabel independen mengalami kenaikan atau penurunan.

Rumus regresi linier sederhana : $Y=a+b_{1} x_{1}+b_{2} x_{2}$ 


\section{Uji Hipotesis}

Uji hipotesis digunakan untuk menguji signifikan atau tidaknya hubungan variabel etos kerja dan kepuasan kerja terhadap kinerja karyawan.

Uji t (analisis persial)

Menurut (Prof.Dr.Sugiyono, 2016, p. 230) menguji korelasi menggunakan uji t yaitu :

thitung $=\frac{r \sqrt{n-2}}{\sqrt{1-r^{2}}}$

pengujian terhadap hipotesis penelitian diatas digunakan dengan membandingkan nilai t ritung dengan tabel. Menurut (Prof.Dr.Sugiyono, 2016, p. 265), uji t digunakan untuk menguji secara parsial masingmasing variabel. Hasil uji t dapat dilihat pada tabel coefisients pada kolom sig (significance). $\mathrm{Uji} \mathrm{t}$ mengetahui secara parsial pengaruh etos kerja dan kepuasan kerja terhadap kinerja.

Menentukan kriteria pengujian

a. Jika t hitung $<\mathrm{t}$ tabel, maka Ho diterima dan Ha ditolak. Jikaterdapat pengaruh etos kerja dan kepuasan kerja terhadap kinerja.

b. Jika t hitung > t tabel, maka Ho ditolak dan Ha diterima. Jikaterdapat pengaruh etos kerja dan kepuasan kerja terhadap kinerja.

\section{Uji F}

Menurut (Prof.Dr.Sugiyono, 2016, p.

234) pengujian signifikan terhadap

koefisien korelasi ganda dengan

menggunakan uji F,yaitu:

F

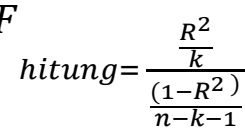

\section{Uji Asumsi Klasik}

Uji asumsi klasik adalah suatu uji yang dibutuhkan untuk memenuhi sebagai model regresi yang baik. Ada terdapat 5 (lima) uji klasik, namun hanya beberapa yang penulis akan gunakan, yaitu sebagai berikut :

Uji normalitas

Uji normalitas berguna untuk menentukan data yang telah dikumpulkan yang telah berdistribusi normal atau diambil dari populasi normal. Uji normalitas yang digunakan adalah tekhnik kolmogorov smirnov digunakan untuk memeriksa apakah data hasil sampling tertentu berasal dari suatu populasi dengan distribusi peluang teoritis tertentu.

Uji homogenitas

Uji homogenitas digunakan untuk mengetahui apakah beberapa varian populasi adalah sama atau tidak. Peneliti perlu melakukan uji kesamaan (homogenitas) beberapa bagian sampel yang diambil dari populasi yang sama. Uji homogenitas bertujuan untuk memastikan bahwa kelompok-kelompok yang dibandingkan merupakan kelompokkelompok yang homogeni. Dalam perhitungan ini, peneliti menggunakan perhitungan statistik tes-F yaitu membandingkan variansi besar dengan variansi terkecil.

Berikut merupakan uji $F$ yang dikutip dari buku (Prof.Dr.Sugiyono, 2016, p. 197):

$F=\frac{\text { variansi terbesar }}{\text { variansi terkecil }}=\frac{s_{1}^{2}}{s_{2}^{2}}$

Hipotesis pengujian : Ho : $\alpha_{1}^{2}=\alpha_{2}^{2}$ (varians data homogen)

H1 : $\alpha_{2}^{2}=\alpha_{1}^{2}$ ( varians data tidak homogen) 
Kriteria pengujian :

Jika $\mathrm{F}$ hitung $\geq \mathrm{F}$ tabel $(0,05$ :dk1:dk2) maka Ho ditolak

Jika $\mathrm{F}$ hitung $\leq$ Ftabel $(0,05$ :dk1:dk2) maka Ho diterima

Uji Linearitas

Uji linearitas digunakan untuk mengetahui apakah pengaruh masing-masing variabel sebagai prediktor mempunyai hubungan linier atau tidak dengan variabel terikat. Contoh penyusunannya :

Menurut Andrew F.Sikula (2012:16), manajemen personalia adalah implementasi dari sumber daya manusia (tenaga kerja) oleh atau dalam suatu perusahaan. Manajemen personalia adalah penarikan, seleksi, penempatan, indoktrinasi, pelatihan dan pengembangan sumber daya manusia oleh dan dalam suatu perusahaan.

Menurut Wayne F.Cascio/ Elias M.Awad (2010:18), manajemen sumber daya manusia adalah penarikan, seleksi, pemeliharaan, dan

Etos kerja dikenal sebagai kata etika, etiket yang hampir mendekati pada pengertian akhlak atau nilai-nilai yang berkaitan dengan baik buruk (moral), sehingga dalam etos tersebut terkandung gairah atau semangatyang amat kuat untuk mengerjakan sesuatu secara optimal, lebih baik dan bahkan berupaya untuk mencapai kualitas kerja yang sesempurna mungkin. Sebagai suatu subjek dari arti etos tersebut adalah etika yang berkaitan dengan konsep yang dimiliki oleh individu maupun kelompok untuk menilai apakah tindakan-tindakan yang telah
Dari asumsi analisis regresi diantaranya linieritas, maksudnya apakah garis regresi antara $\mathrm{X}$ dan $\mathrm{Y}$ membentuk garis linier atau tidak. Kalau tidak linier maka analisis regresi tidak dapat dilanjutkan. (Prof.Dr.Sugiyono, 2016, p. 265)

$F=\frac{R^{2}(n-m-1)}{m\left(1-R^{2}\right)}$

\section{Tinjauan Pustaka}

\section{Manajemen Sumber Daya Manusia}

penggunaan sumber daya manusia untuk mengaktifkan baik tujuan individual maupun organisasi.

Dari beberapa definisi diatas, dapat disimpulkan bahwa manajemen sumber daya manusia adalah ilmu dan seni yang mengatur unsur manusia (cipta, rasa, dan karsa) sebagai aset suatu organisasi demi terwujudnya tujuan organisasi dengan cara memperoleh, mengembangkan dan memelihara tenaga kerja secara efektif dan efisien.

\section{Etos Kerja}

dikerjakan itu salah atau benar,buruk atau baik.

Menurut Sinamo (2005:151), etos kerja adalah seperangkat perilaku positif yang berakar pada keyakinan fundamental yang disertai komitmen total pada paradigma kerja yang integral. Menurutnya, jika seseorang, suatu organisasi atau suatu komunitas menganut suatu paradigma kerja, mempercayai, dan berkomitmen pada paradigma kerja tersebut, semua itu akan melahirkan sikap dan perilaku kerja mereka yang khas. Itulah yang akan menjadi budaya kerja. 
Dari berbagai definisi di atas dapat dikatakan bahwa etos kerja adalah cara pandang seseorang dalam menyikapi, melakukan dan bertindak

Menurut Edy Sutrisno (2014:73), kepuasan kerja menjadi masalah yang cukup menarik dan penting, karena terbukti besar manfaatnya bagi kepentingan individu, industri dan masyarakat.

Richard, Robert dan Gordon (2012:312,337) menegaskan bahwa kepuasan kerja berhubungan dengan perasaan atau sikap seseorang mengenai pekerjaan itu sendiri, gaji, kesempatan promosi atau pendidikan, pengawasan, rekan kerja, beban kerja dan lain-lain. Ia melanjutkan pernyataanya bahwa

Landasan yang sesungguhnya dalam suatu organisasi adalah kinerja. Jika tidak ada kinerja maka seluruh bagian organisasi, maka tujuan tidak dapat tercapai. Kinerja perlu dijadikan sebagai bahan evaluasi bagi pemimpin atau manajer.Dalam Kamus Besar Bahasa Indonesia yang dikutip dan Diterjemahkan oleh Hadari Nawawi (2006:63), mengatakan bahwa "Kinerja adalah (a) sesuatu yang dicapai, (b) prestasi yang diperlihatkan, (c) kemampuan kerja".Definisi lain mengenai kinerja menurut Hadari Nawawi (2006:63) adalah "Kinerja dikatakan tinggi apabila suatu target kerja dapat diselesaikan pada waktu yang tepat atau tidak melampui batas waktu yang disediakan". Kinerja menjadi rendah jika diselesaikan melampui batas waktu yang disediakan atau sama sekali tidak terselesaikan. dalam bekerja, dengan kemauan organisasi, instansi maupun perusahaan sehingga pekerjaan dapat dilaksanakan dengan baik

\section{Kepuasan Kerja}

kepuasan kerja berhubungan dengan sikap seeorang mengenai kerja, dan ada beberapa alasan praktis yang membuat kepuasan kerja merupakan konsep yang penting bagi pemimpin. Pekerja yang puas juga cenderung terlibat dalam perilaku organisasi yang melampaui deskripsi tugas dan peran mereka, serta membantu mengurangi beban kerja dan tingkat stress anggota dalam organisasi. Pekerja yang tidak puas cenderung bersikap menentang dalam hubungannya dengan kepemimpinan dan terlibat dalam berbagai perilaku yang kontraproduktif.

\section{Kinerja}

Menurut Drs.H.Malayu S.P. Hasibuan (2014:94), menjelaskan bahwa, "Kinerja merupakan hasil kerja yang dicapai seseorang dalam melaksanakan tugas-tugas yang dibebankan kepadanya didasarkan atas kecakapan, pengalaman, kesungguhan serta waktu". Sedangkan menurut Suyadi Prawirosentono (2008:2), "Kinerja atau dalam bahasa inggris adalah performance", yaitu: Hasil kerja yang dapat dicapai oleh seseorang atau sekelompok orang dalam organisasi, sesuai dengan wewenang dan tanggung jawab masing-masing dalam rangka upaya mencapai tujuan organisasi bersangkutan secara legal, tidak melanggar hukum dan sesuai dengan moral maupun etika.

Dari beberapa pengertian diatas,dapat disimpulkan bahwa kinerja karyawan adalah kemampuan 
mencapai persyaratan-persyaratan pekerjaan, dimana suatu target kerja dapat diselesaikan pada waktu yang tepat atau tidak melampui batas waktu yang disediakan sehingga

Dalam proses mendapatkan data penelitian mengenai persepsi yang berkaitan dengan pengaruh etos kerja dan kepuasan kerja terhadap kinerja karyawan PT.Mercedes Benz Indonesia, dalam usaha pengambilan sampel penulis menggunakan sebagian karyawan yang ada pada PT.Mercedes Benz Indonesia yang berlokasi di Jalan Raya Mercedez Benz, Wanaherang, Gunung Putri, Cicadas, Bogor, Jawa Barat 16965.

Peneliti membagikan kuesioner kepada para karyawan yang mewakili di PT.Mercedes Benz Indonesia dengan mengunakan teknik random sampling atau secara acak. tujuannya akan sesuai dengan moral maupun etika perusahaan. Dengan demikian kinerja karyawan dapat memberikan kontribusi bagi perusahaan tersebut

\section{Hasil dan Pembahasan}

Daftar pertanyaan yang diajukan bersifat tertutup dengan alternatif jawaban yang telah disediakan. Jumlah pernyataan yang ada pada kuesioner berjumlah 30 pernyataan, terdiri dari 10 pernyataan mengenai variabel etos kerja $\left(\mathrm{X}_{1}\right), \quad 10$ pernyataan mengenai variabel kepuasan kerja $\left(\mathrm{X}_{2}\right)$, dan 10 pernyataan mengenai variabel kinerja (Y). Dengan data hasil kuesioner yang telah disebar dapat diketahui sejauh mana pengaruh etos kerja dan kepuasan kerja terhadap kinerja karyawan PT.Mercedes Benz Indonesia.

Tabel 1

Hasil Penelitian

Analisis Regresi Etos Kerja (X) Terhadap Kinerja (Y)

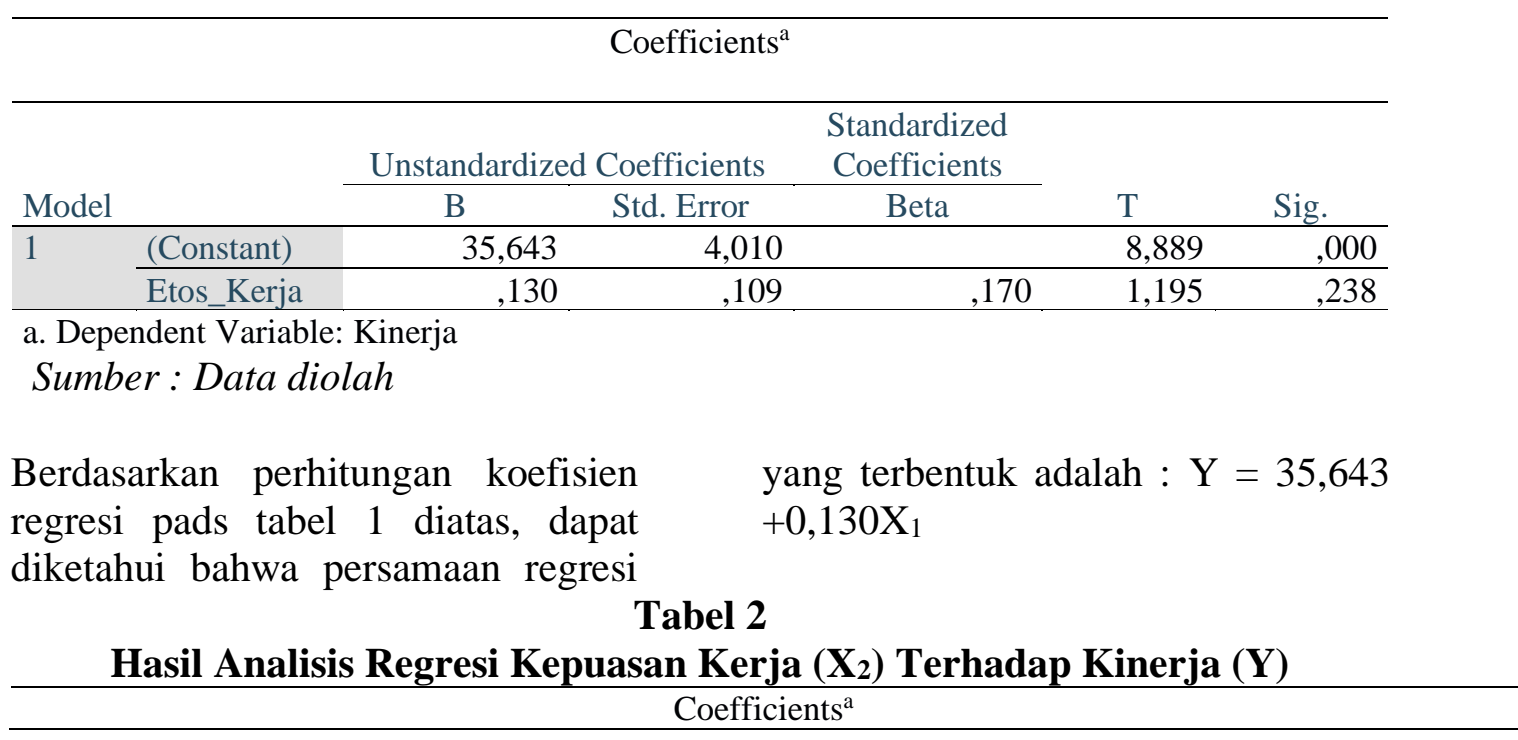




\begin{tabular}{|c|c|c|c|c|c|c|}
\hline \multirow{2}{*}{\multicolumn{2}{|c|}{ Model }} & \multicolumn{2}{|c|}{ Unstandardized Coefficients } & $\begin{array}{l}\text { Standardized } \\
\text { Coefficients }\end{array}$ & \multirow[b]{2}{*}{$\mathrm{T}$} & \multirow[b]{2}{*}{ Sig. } \\
\hline & & $\mathrm{B}$ & Std. Error & Beta & & \\
\hline \multirow[t]{2}{*}{1} & (Constant) & 37,345 & 3,594 & & 10,391 &, 000 \\
\hline & Kepuasan_Kerja & ,089 & 104 & 123 & ,858 & ,395 \\
\hline
\end{tabular}

a. Dependent Variable: Kinerja

\section{Sumber : Data diolah}

Berdasarkan perhitungan koefisein regresi pada tabel 2 diatas, dapat yang terbentuk adalah : $\mathrm{Y}=37,345+$ diketahui bahwa persamaan regresi

Tabel 3

\section{Hasil Analisis Regresi Etos Kerja (X) Dan Kepuasan Kerja $\left(\mathbf{X}_{2}\right)$ Terhadap} Kinerja (Y)

Coefficients $^{\mathrm{a}}$

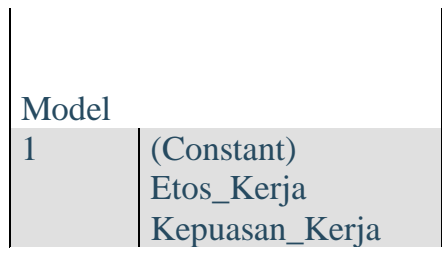

\begin{tabular}{|c|c|}
\hline Instandardiz & Coefficients \\
\hline B & Std. Error \\
\hline 29,008 & 6,408 \\
\hline , 178 &, 114 \\
\hline, 142 & ,108 \\
\hline
\end{tabular}

Standardized
Coefficients
Beta
,232
, 197

\begin{tabular}{r|r|} 
& \\
$T$ & Sig. \\
4,526 &, 000 \\
1,561 &, 125 \\
1,321 &, 193
\end{tabular}

a. Dependent Variable: Kinerja

Sumber : Data diolah

Berdasarkan perhitungan koefisien yang terbentuk adalah: $\mathrm{Y}=29,008+$ regresi pada tabel 3 diatas, dapat $0,178 \mathrm{X}_{1}+0,142 \mathrm{X}_{2}$ diketahui bahwa persamaan regresi

\section{Tabel 4}

\section{Hasil Analisis Korelasi Etos Kerja Terhadap Kinerja}

Model Summary ${ }^{\mathrm{b}}$

\begin{tabular}{lcccc}
\hline Model & $\mathrm{R}$ & $\mathrm{R}$ Square & Adjusted R Square & Std. Error of the Estimate \\
\hline 1 & $170^{\mathrm{a}}$ &, 029 &, 009 & 3,35994 \\
\hline a. Predictors: (Constant), Etos_Kerja & & & \\
\hline \\
b. Dependent Variable: Kinerja \\
sumber: data diolah
\end{tabular}

Berdasarkan tabel 4 diatas, $\mathrm{R}=0,170$ terletak pada interval $(0,00-0,199)$, hal ini menunjukkan bahwa hubungan antara variabel etos kerja dan kinerja adalah sangat rendah serta arah hubungan adalah positif karena nilai $\mathrm{r}$ positif, berarti apabila $\mathrm{X} 1$ naik maka Y naik dan sebaliknya apabila X1 turun maka Y juga turun.

Tabel 5 
Hasil Analisis Korelasi Kepuasan Kerja $\left(\mathbf{X}_{2}\right)$ Terhadap Kinerja (Y) Model Summary ${ }^{\mathrm{b}}$

\begin{tabular}{lrrrr} 
Model & $\mathrm{R}$ & R Square & Adjusted R Square & $\begin{array}{c}\text { Std. Error of the } \\
\text { Estimate }\end{array}$ \\
\hline 1 &, $123^{\text {a }}$ &, 015 &,- 005 & 3,38372 \\
\hline
\end{tabular}

a. Predictors: (Constant), Kepuasan_Kerja

b. Dependent Variable: Kinerja

\section{Sumber : Data diolah}

Berdasarkan tabel diatas, $\mathrm{R}=0,123$ terletak pada interval $(0,00-0,199)$, hal ini menunjukkan bahwa hubungan antara variabel etos kerja dan kinerja adalah sangat rendah

\section{Tabel 6}

Hasil Analisis Korelasi Etos Kerja $\left(\mathrm{X}_{1}\right)$ dan

Kepuasan Kerja (X2) Terhadap Kinerja (Y) serta arah hubungan adalah positif karena nilai $\mathrm{r}$ positif, berarti apabila $\mathrm{X}_{2}$ naik maka $\mathrm{Y}$ naik dan sebaliknya apabila $\mathrm{X}_{2}$ turun maka $\mathrm{Y}$ juga turun.

Model Summary ${ }^{\mathrm{b}}$

\begin{tabular}{lrrrr}
\hline Model & R & R Square & Adjusted R Square & $\begin{array}{c}\text { Std. Error of the } \\
\text { Estimate }\end{array}$ \\
\hline 1 &, $252^{\text {a }}$ &, 064 &, 024 & 3,33419 \\
\hline
\end{tabular}

a. Predictors: (Constant), Kepuasan_Kerja, Etos_Kerja

b. Dependent Variable: Kinerja

\section{Sumber : Data diolah}

Berdasarkan tabel diatas,

$\mathrm{R}=0,252$ terletak pada interval $(0,20$

- 0, 399 ), hal ini menunjukkan bahwa hubungan antara variabel etos kerja dan kepuasan kerja secara

bersama-sama terhadap kinerja adalah rendah serta arah hubungan adalah positif karena nilai $\mathrm{r}$ positif, berarti apabila $X_{1}$ dan $X_{2}$ naik maka $Y$ juga naik dan sebaliknya apabila $\mathrm{X}_{1}$ dan $\mathrm{X}_{2}$ turun maka $\mathrm{Y}$ juga turun.

Tabel 7

Hasil Uji F (Analisis Simultan) Antara Etos Kerja ( $\left.\mathbf{X}_{1}\right)$ Dan Kepuasan Kerja $\left(\mathbf{X}_{2}\right)$ Terhadap Kinerja (Y)

ANOVA $^{\mathrm{a}}$

\begin{tabular}{|c|c|c|c|c|c|c|}
\hline Model & & Sum of Squares & df & Mean Square & $\mathrm{F}$ & Sig. \\
\hline \multirow[t]{3}{*}{1} & Regression & 35,509 & 2 & 17,754 & 1,597 &, $213^{\mathrm{b}}$ \\
\hline & Residual & 522,491 & 47 & 11,117 & & \\
\hline & Total & 558,000 & 49 & & & \\
\hline
\end{tabular}

a. Dependent Variable: Kinerja

b. Predictors: (Constant), Etos_Kerja, Kepuasan_Kerja

Sumber : Data diolah 
Uji f (Analisis simultan)

1. Formula Hipotesis

Ho = Tidak terdapat pengaruh etos kerja dan kepuasan kerja terhadap kinerja karyawan

$\mathrm{Ha}=$ Terdapat pengaruh etos kerja dan kepuasan terhadap kinerja karyawan

2. Taraf Nyata $(\alpha)$ dan $f_{\text {tabel }}$

Taraf nyata $95 \%$, nilai $\alpha=5 \%$ atau 0,05

3. Nilai $f_{\text {tabel }}$

Df1 $=\mathrm{dk}$ pembilang $=\mathrm{k}-1=2$

Df2 $=$ dk penyebut $=\mathrm{n}-\mathrm{k}-1=50-$ $2-1=47$

$\mathrm{f}_{\text {tabel }}=3,20$

\section{Kesimpulan dan Saran}

\section{Kesimpulan}

Analisis antara etos kerja dengan kinerja karyawan menunjukkan terdapat pengaruh yang positif dan signifikan. Hal ini ditunjukkan dari hasil persamaan regresi $\mathrm{Y}=35,643+$ $0,130 \quad \mathrm{X}_{1}$ dengan intrepretasi Variabel $\mathrm{X}_{1}$ (Etos Kerja) sebesar 0,130 , ini berarti pengaruh etos kerja terhadap kinerja karyawan adalah positif atau setiap kenaikan skor variabel $\mathrm{X}_{1}$ (Etos Kerja) sebesar 1, maka akan meningkatkan nilai skor variabel Y sebesar 0,130.

Dari hasil perhitungan analisis koefisien korelasi $\mathrm{R}=0,170$, terletak pada interval $(0,00-0,199)$ yang menunjukkan bahwa hubungan antara etos kerja terhadap kinerja karyawan adalah rendah. Dari hasil koefisen determinasi sebesar 0,029 atau 2,9\% memberikan arti bahwa besarnya pengaruh etos kerja terhadap kinerja karyawan sebesar $2,9 \%$ sedangkan sisanya sebesar $97,1 \%$ dipengaruhi oleh faktor-faktor
4. Kriteria pengujian

Ho diterima dan Ha ditolak apabila

$\mathrm{f}_{\text {hitung }}<\mathrm{f}_{\text {tabel }}$

Ho ditolak dan Ha diterima apabila $\mathrm{f}_{\text {hitung }}>\mathrm{f}_{\text {tabel }}$

5. Nilai uji statistik

Berdasarkan perhitungan dengan aplikasi komputer dapat dilihat pada tabel 7 Bahwa $\mathrm{f}_{\text {hitung }}=1,597$

6. Kesimpulan

Karena $f_{\text {hitung }}=1,597<\mathrm{f}_{\text {tabel }}=3,20$, maka Ho ditolak Ha diterima, berarti tidak terdapat pengaruh yang signifikan antara etos kerja dan kepuasan kerja terhadap kinerja karyawan.

lain yang tidak dimasukkan dalam penelitian ini.

Selanjutnya dari hasil uji hipotesis pada taraf kesalahan 5\% adalah thitung $=1,195>\mathrm{t}_{\text {tabel }}=1,67$, maka Ho ditolak Ha diterima, berarti tidak terdapat pengaruh yang signifikan antara etos kerja dengan kinerja karyawan.

Analisis antara kepuasan kerja dengan kinerja karyawan menunjukkan terdapat pengaruh yang positif dan signifikan. Hal ini ditunjukkan dari hasil persamaan regresi $\mathrm{Y}=37,345+0,089 \mathrm{X}_{2}$ dengan intrepretasi Variabel $\mathrm{X}_{2}$ (kepuasan Kerja) sebesar 0,089, ini berarti pengaruh kepuasan kerja terhadap kinerja karyawan adalah positif atau setiap kenaikan skor variabel $\mathrm{X}_{1}$ (Etos Kerja) sebesar 1, maka akan meningkatkan nilai skor variabel $\mathrm{Y}$ sebesar 0,089.

Dari hasil perhitungan analisis koefisien korelasi $\mathrm{R}=0,123$, terletak 
pada interval $(0,00-0,199)$ yang menunjukkan bahwa hubungan antara kepuasan kerja terhadap kinerja karyawan adalah rendah. Dari hasil koefisen determinasi sebesar 0,015 atau $1,5 \%$ memberikan arti bahwa besarnya pengaruh etos kerja terhadap kinerja karyawan sebesar $1,5 \%$ sedangkan sisanya sebesar 98,5\% dipengaruhi oleh faktor-faktor lain yang tidak dimasukkan dalam penelitian ini.

Selanjutnya dari hasil uji hipotesis pada taraf kesalahan $5 \%$ adalah $t_{\text {hitung }}$ $=1,195>\mathrm{t}_{\text {tabel }}=0,0858$, maka Ho diterima Ha ditolak, berarti terdapat pengaruh yang signifikan antara etos kerja dengan kinerja karyawan.

Analisis antara kepuasan kerja dengan kinerja karyawan menunjukkan terdapat pengaruh yang positif dan signifikan. Hal ini ditunjukkan dari hasil persamaan regresi $\mathrm{Y}=29,008+0,178 \mathrm{X}_{1}+$ $0,142 X_{2}$ dengan intrepretasi variabel $\mathrm{X}_{1}$ (etos kerja) sebesar 0,178 dan intrepretasi variabel $\mathrm{X}_{2}$ (kepuasan kerja) sebesar 0,142, ini berarti pengaruh etos kerja dan kepuasan Saran

Berdasarkan hasil kesimpulan dalam penelitian ini, berikut merupakan pertimbangan atau saran yang diharapkan dapat dijadikan sebagai bahan masukkan dan pertimbangan guna meningkatkan kinerja karyawan PT. Mercedes Benz Indonesia.

Dari hasil rekapitulasi persepsi responden terhadap variabel etos kerja yang dilakukan berdasarkan indikator yang telah ditetapkan, menunjukkan bahwa dalam menyelesaikan masalah terjadi kesenjangan atau tidak dapat diatasi dengan baik. Hal ini dapat dilihat dari pernyataan nomor 10 dengan kerja terhadap kinerja karyawan adalah positif atau setiap kenaikan skor variabel $\mathrm{X}_{1}$ (Etos Kerja) sebesar 1, maka akan meningkatkan nilai skor variabel $\mathrm{Y}$ sebesar 0,0178 dan setiap kenaikan skor variabel $\mathrm{X}_{2}$ ( kepuasan kerja) sebesar 1, maka akan meningkat nilai skor variabel $\mathrm{Y}$ sebesar 0,142 .

Dari hasil perhitungan analisis koefisien korelasi $\mathrm{R}=0,252$ terletak pada interval $(0,20-0,399)$ yang menunjukkan bahwa hubungan antara etos kerja dan kepuasan kerja terhadap kinerja karyawan adalah rendah. Dari hasil koefisen determinasi sebesar 0,064 atau 6,4\% memberikan arti bahwa besarnya pengaruh etos kerja terhadap kinerja karyawan sebesar 2,4\% sedangkan sisanya sebesar $97,6 \%$ dipengaruhi oleh faktor-faktor lain yang tidak dimasukkan dalam penelitian ini.

Selanjutnya dari hasil uji hipotesis pada taraf kesalahan 5\% adalah $\mathrm{f}_{\text {hitung }}$ $=1,597<\mathrm{f}_{\text {tabel }}=3,20$, maka Ho ditolak Ha diterima, berarti tidak terdapat pengaruh yang signifikan antara etos kerja dan kepuasan kerja terhadap kinerja karyawan.

presentase $68 \%$ perusahaan kurang dalam menyelesaikan masalah. Dalam hal ini peneliti mencoba memberi masukkan, yaitu untuk manager perusahaan untuk lebih sering mengadakan rapat atau pertemuan guna membahas pola komunikasi atau koordinasi dalam pemecahan masalah agar dapat terjalin keselarasan dalam pemecahan setiap masalah. Manager juga harus tahu dimana letak permasalahan dan bagaimana cara mengatasinya.

Dari hasil rekapitulasi persepsi responden terhadap variabel 
kepuasan kerja yang dilakukan berdasarkan indikator yang telah ditetapkan, menunjukkan bahwa hubungan antara karyawan yang kurang baik. Hal ini dapat dilihat pada pernyataan nomor 7 dengan antar karyawan. Agar kepuasan kerja bisa terwujud sehingga meningkatkan kinerja karyawan itu sendiri.

Dari hasil rekapitulasi persepsi responden terhadap variabel kinerja yang dilakukan berdasarkan indikator yang telah ditetapkan, menunjukkan bahwa kurangnya

\section{Daftar Pustaka}

Hasibuan, M. S. P. (2014).

Manajemen Dasar,

Pengertian dan Masalah.

CV. Haji Masagung.

M.Azis Firdaus,SE.,MM. (2016).

Metodologi Penelitian.

Jelajah Nusa.

Nawawi, H. (2006). Evaluasi dan

Manajemen Kinerja di

Lingkungan Perusahaan dan

Industri. Gadjah Mada

University Press.

Prawirosentono, S. (2008).

Manajemen Sumber Daya

ManusiaKebijakan Kinerja

Karyawan. BPFE.

Prof.Dr.Sugiyono. (2016). Metode

Penelitian (Kuantitatif,

Kualitatid Dan R \& D).

Sinamo, \& Jansen. (2005). Delapan

Etos Kerja Profesional

(Navigator Anda Menuju

Sukses.

Sugiyono. (2015). Metode Penelitian

Kuantitatif, Kualitatif, dan

$R \& D$. Alfabeta. presentase $48 \%$ dari jawaban responden. Dalam hal ini peneliti mencoba memberi masukkan, yaitu dengan diadakan nya kegiatan kegiatan yang dapat menumbuhkan nilai kerjasama

kedisiplinan para pekerja. Hal ini dapat dilihat dari pernyataan nomor 3 dengan presentase $46 \%$ dari jawaban responden. Dalam hal ini peneliti mencoba memberi masukkan, yaitu dengan memberikan reward bagi yang disiplin dalam pekerjaannya dan memberikan punishment bagi pekerja yang terlambat atau tidak disiplin saat masuk kerja.

Suharsimi, A. (2002). Metodologi Penelitian. PT. Rineka Cipta.

Sutrisno, H. E. (2014). Manajemen sumber daya manusia. Edisi pertama, Cetakan, 6 . 